\title{
THE IMPACT OF TUBERGULOSIS ON HISTORY, LITERATURE AND ART
}

\author{
by \\ H. D. GHALKE \\ If men could learn from history, what lessons it might teach us! \\ S. T. COLERIDGE
}

\section{INTRODUCTION}

DiseAse has had an incalculable influence on the history of mankind. The earliest records tell of plagues and pestilences which devastated whole countries and had profound effects on social structure, contributing to unrest, famine, migration and wars.

But 'history is the essence of unnumerable biographies' and so individual illhealth, both mental and physical, has had a great impact on world events, and on the Arts-literature, poetry, painting and music. A study of the biographies of the famous shows how often they have been dogged by illness of the mind or body, and it is interesting to speculate as to the effect this may have had on their outlook, productivity or scholarship. Consider also what those geniuses in the world of poetry or music who died young might have achieved had they lived! There is no doubt, either, that illness and early death of the parents plays a part in determining the habits and character of the children. Tuberculosis when it was in its epidemic phases in this country exemplifies this.

The story of tuberculosis gives us, perhaps, as good a picture as any of the impact of disease on life and culture. Apart from leprosy, western civilization has known no communicable disease which may run such a protracted course, affecting almost any part of the body and giving rise to such long periods of ill-health and disablement.

\section{HISTORY}

No one can tell when the tubercle bacillus first became a parasite of man, or how infection began. There are at least some grounds for the supposition that it was of bovine origin, but whatever its source, man and his animals seem to have been affected a very long time ago. As a communicable disease, its spread would have been restricted until isolated groups of people began to adopt a wider community existence, sharing their dwellings with the sheep, pigs and cattle that had become domesticated (? c. 12,000 years ago), and extending their outside contacts. Movement farther afield as trade routes opened up (the horse, domesticated much later than the other animals, helped to make this possible) and the growth of centres of barter at the junctions of these routes and at the sea terminals, would aid the passage of infection. The human drift in search of game and better pasture was intensified as population increased; and with greater numbers at risk, in the less hospitable climates to the west and north in 


\section{H. D. Chalke}

the wake of the retreating ice, more and more people would be prone to pulmonary complaints.

About 10,000 B.c. Neolithic man was moving into Europe, by 5000 B.c. leading a community life in lake dwellings. It seems that horseflesh was no longer used as a human food (the horse was not apparently as subject to tuberculosis as the cow or pig which were eaten in its place), and cow's milk became part of the diet. The thoracic vertebrae seen in a Neolithic skeleton found at Heidelberg, show collapse, strongly suggestive of tuberculous infection. The basins of the Nile, and the Tigris and Euphrates, cradled civilization in 5000-3000 B.C. It is understood that tuberculosis is not mentioned in the Ebers Papyrus, nor in the code of laws of Hammurabi of Babylon (2250 B.c.) (Burke). Elliot Smith found evidence of tuberculosis in five out of ro,ooo Egyptian skeletons, the earliest dated 3500 B.c. and, quite recently, palaeopathology has revealed spinal caries and a psoas abscess in a mummy of the XXIst dynasty (c. IOoO B.c.). But the ancient Egyptians left no accounts of tuberculosis: the standard of health was high, as Herodotus (c. 400 B.c.), the traveller and descriptive writer, confirmed - though some centuries later.

Neither the Old nor the New Testaments give acceptable information of a disease such as the respiratory tuberculosis of modern times (Fraser). It is not to be found in the Mosaic Code, but the description in the Talmud of caseous nodules in the lungs of animals is noteworthy. Frazer (The Golden Bough) says that the Hindoos in Vedic times ( 1500 B.c.) sang: ' $O$ consumption fly away with the Blue Jay': but 'consumption' in relation to those days may be a vague appellation. Did they-if indeed they knew phthisis in that era-receive the infection from the East or from the West? The latter appears to be the more probable in view of the early lines of communication between the two. It must be noted that, according to Francis, tuberculosis was common in domesticated wild elephants in ancient Hindoo times.

\section{Cattle}

A treatise on animal diseases written in A.D. 420 describes cough and emaciation, or consumption, as a serious disease of cattle. A tomb in Asia Minor, of a child of four and a half years dying in the third century B.c., records death from disease of the testicles, foot and intestines, with wasting of other parts: 'I have left the hated consumption as a heritage to my survivors' (Meinecke). The movement of herds of Lombardy cattle across Europe which commenced in the thirteenth century, and steadily increased, could conceivably have been linked with the high incidence of scrofula and other manifestations of bovine tuberculosis in man which continued until the present century.

\section{Recent Discoveries}

Theories about the beginnings of tuberculosis as a disease of man, and suppositions as to its first vectors, must be modified in the light of recent findings in palaeopathology, and the more accurate determination of the age of human and animal remains which carbon-14 estimation has made possible. Of 


\section{The Impact of Tuberculosis on History, Literature and Art}

outstanding interest in this connexion is the discovery of Pott's Disease, and rib deformity believed to be evidence of tuberculous disease of the chest, in a Californian skeleton (c. 400 B.C.) (Roney).

It is said that America had no aborigines, and that its first men crossed from Asia after the palaeolithic period (c. I5,000-10,000 B.c.) when the two continents had only a short stretch of sea between them. After that time they appear to have been cut off from the Old World for many millennia. They had no domestic animals (the bison was untameable), and there was probably negligible tribal contact in a continent so vast, and so sparsely peopled. Was the disease already present among those who crossed from Asia to Alaska, and was the infection brought by the white man something they had known before? Among the first British allusions are those by Taliesin, the sixth century Welsh poet ('phthysis is one of the three tedious diseases'), and the Physicians of Myddfai who gave mouse dung for blood-spitting (Red Book of Hergest, $\mathrm{I} 3^{\text {th }}$ century). Evidence of probable tuberculosis in early Saxon skeletons is discussed by Brothwell.

Thus, whilst there is little doubt about the antiquity of non-pulmonary manifestations the extent and distribution of respiratory tuberculosis in ancient times is far more speculative. Yet, one wonders what part it may have played in the demise of those ancient civilizations whose history is lost. The balance of evidence suggests, however, that originally, phthisis was not an important disease of hot climates.

But there are more authentic facts about tuberculosis in classical antiquity, when phthisis-a wasting sickness with cough-must have been common. It was Hippocrates (400 B.c.) who gave the first clear description of consumption, and his writings have been quoted by doctors ever since, not always accurately, and often with the doubtful assumption-because of the frequent references to it in his works-that tuberculosis was very widely prevalent at that time. Its infectivity was suspected even in those remote days at least 2,200 years before Koch discovered the organism: Aristotle (d. 322 B.c.) wondered why those in contact with sufferers took phthisis, but did not do so after contact with dropsy.

\section{Saxon and Medieval Britain*}

Little is known about phthisis in Saxon and Medieval England, an epoch not remarkable for advances in medical knowledge. The killers of the age were epidemic diseases such as plague, typhus, smallpox and the sweating sickness, which removed many of those who might have succumbed to the more chronic phthisis. The country was sparsely populated, $\dagger$ travel was limited, and industrialization had not begun. But although there is nothing to suggest that consumption was a major disease, it seems that leprosy was. Brought to Europe by the Army of Pompey in 6I B.C., by A.D. 620, according to the chroniclers, it was common in England: in the thirteenth century soldiers returning from the Crusades brought more infection with them, but in the next 300 years it slowly

* Recent examinations of 290 skeletons in the Roman-British cemetery at York-'the largest and most significant find of its kind ever made'-yielded no evidence of tuberculous disease. Eburacum, Roman Tork, H.M.S.O., I962, I.

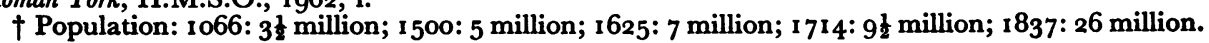




\section{H. D. Chalke}

diminished and eventually disappeared altogether, to be replaced by its first cousin, consumption, which may now be following the same path.

\section{Scrofula-the King's Evil}

There is much more to be learned about a non-pulmonary form of tuberculosis, tuberculous adenitis or scrofula (from scrofa, a sow 'because these animals are subject to it'), which seems to have been abundant at that time. Supposed to be curable by the touch of a king, it was called the King's Evil. William of Malmesbury, the eleventh-century historian, records the royal touch as early as Edward the Confessor's reign. The physician to the Court of Edward II, John of Gaddesden, who wrote Rosa Anglica in 1320, exhorted sufferers from scrofula to apply for the Royal Touch if 'sovereign remedies' such as the blood of a weasel or dove's dung did not bring speedy improvement. Pepys and Evelyn give graphic descriptions of the ceremonies during Stuart times, when the press of people was so great that many were crushed to death: John Brown, surgeon to Charles II, calculated that the king touched nearly 100,000 between I66o and 1682 . Brown believed deaths from scrofula to be 'the highest ever', an increase he associated with the king's absence. Richard Wiseman, Serjeant Chyrurgeon to Charles II, noted that the blood of Charles I gathered after his execution 'on chips and handkerchiefs' had the same healing powers.

Dr. Richard Morton, I689, who added much to knowledge of tuberculosis, separated scrofula into tuberculous and non-tuberculous forms; the tendency to spontaneous improvement to which he drew attention, and inaccuracy of diagnosis, must have accounted for many of the miraculous cures. Misconceptions about the aetiology of this complaint lasted a long time, and confused the new pathology of tuberculosis so ably demonstrated by Matthew Baillie a century later. (As late as $189 \mathrm{I}$, in a Manual of Domestic Medicine by 'Physicians and Surgeons of the Principal London Hospitals' it is stated categorically that scrofula though often confounded with tuberculosis is quite distinct from it despite the occasional similarity of symptoms.) But despite diagnostic confusion, the evidence suggests a high prevalence of disease of bovine origin at that time. There is a descriptive passage in Macbeth: 'Tis called the evil . . . strangely visited people all swoln and ulcerous, pitiful to the eye, the mere despair of surgery.'

Samuel Johnson was a sufferer. Queen Anne, the last English monarch to practise the Royal Touch, touched him when he was five years old, apparently without benefit. Johnson is an example of a genius whose characteristics should be considered in relation to his disability. He had a huge body, much disfigured by scrofulous scars, and a mighty mind, but 'disease of the spirits'; in his own words: 'There are perhaps few conditions more to be pitied than that of an active and elevated mind labouring under the weight of a distempered body.'

THE GROWTH OF PHTHISIS IN BRITAIN

The student of epidemiological history is hampered by the absence of accurate statistical facts. Bills of Mortality began in London in 1532, a plague 


\section{The Impact of Tuberculosis on History, Literature and Art}

year, and continued intermittently to begin with until 1836 , when the Births and Deaths Registration Act was passed. Notification of all forms of tuberculosis is as recent as 1912. The Bills gave only the proportionate mortality and not the death-rate per unit of population: the recorded cause of death was that given by the old women who acted as searchers, who have been described as drunken, venal and ignorant, easily bribed and ready to write 'consumption' when paid to conceal the presence of plague. Despite these inaccuracies, much can be deduced from the Bills. John Graunt (I662), a pioneer statistician, made the comment that the searchers could not tell whether emaciation and leanness were from phthisis or 'hectick fever'. By 1799 consumption was given as the cause of one out of every four deaths in London. W. Woolcombe, M.D., in 1818 published a masterly analysis of the data and also of figures obtained from parish registers and public dispensary returns. He found that the absolute and relative mortality from consumption had increased in many parts of the country since I 700- 'the rate was so high as almost to exceed belief'. In a secluded Shropshire village, for example, the parish registers revealed a comparative mortality of one in six between $175^{\circ}$ and 1759 , which in the next ten years rose to one in three. In other places, also, local epidemics were occurring. It seems that this was an epidemic phase in England, which showed little decline until the I83os.

\section{CAUSATIVE FACTORS}

What were the factors contributing to this spread of tuberculosis? There are many possibilities. The Restoration brought profound changes in the English way of life. The country became more prosperous, there was an improvement in the state of society and travel became easier; yet, within a century misery and wretchedness abounded and 1,200,000 of the 8,800,000 inhabitants were receiving parish relief.

The influx of susceptibles from rural England to London after the 'poore plague', consisted chiefly of persons 'at that period of life deemed most liable to invasion of phthisical disease'. For a time, we are told, there was a large number of weakly children reared who 'in a less improved state of society must have perished in infancy'. If it is agreed that the key to adult tuberculosis is to be found in childhood infection, the infants of that time may have laid the foundations of the adult consumption which later on spread over Britain.

\section{Race and Environment}

Housing, nutrition, habits, overcrowding, income, climate, occupation, psychological factors and racial susceptibility have time and again been cited as influences affecting phthisis morbidity and mortality, but as yet the role of the individual items has not been ascertained with any accuracy. The skein has not been unravelled. It will not be overlooked that the rise in tuberculosis started long before the Industrial Revolution of the $1780 \mathrm{os}$, and began to fall at a time when hygiene and sanitation were of a low order, cholera and typhoid menaced the country, and maternal and infant deaths were excessive. Life was harsh and cheap: the only legislative welfare service was the Poor Law. 
Brownlee, commenting on the rise and fall of epidemics, thought that germs may undergo mutation and that the generation of an epidemic depended on the right mutation, corresponding with a suitable disposition of the population at risk. Today, can much more be said?

Young in a signal contribution to medical literature (1815) showed how the phthisis mortality varied in different parts of Britain and in other countries. There may be significance in the fact that the more isolated places-parts of Scotland, Wales and Ireland-do not appear to have met tuberculosis in epidemic form until more than roo years after urban England. The decline in these countries has been correspondingly delayed. In places such as Nepal and Puerto Rico, tuberculosis is in epidemic form today. (The mass radiography of Gurkha soldiers reveals an incidence of 14.8 per 1,000 .) Brownlee found that in Pembrokeshire a line could be drawn across the county, above it the tuberculosis rate was high, below it, low. In the north the people are Welsh of Iberian stock; those to the south are the descendants of the Normans. The anthropological characters are still evident, the place-names and language are different. Mining (coal, lead, slate, etc.), under-nourishment and tuberculous cattle, weighted the scales against the susceptible Welsh.

In due course some influence comes into action, which Newsholme thought prevents the excessive tuberculosis which an adverse environment evokes. He cited Ireland, where housing improvements did not retard the rising phthisis mortality; for some time in the U.S.A. it remained excessive, despite better living conditions-a higher racial resistance had not yet been acquired, and as happened to many other races, the Irish were not yet able to withstand the massive and repeated infection which beset them in urban life. The wider question of the origins, antiquity and recent incidence of tuberculosis in the several races of the Americas, New Zealand, Africa and eastern countries is of great interest, but it is too large and complex to be discussed here. More primitive peoples may be suffering from exposure to a new infection, or an old infection reintroduced, to which immunity has been lost. They are fortunate in having new methods of prevention and treatment to aid them, and in being able to take advantage of the experiences of those countries, which after centuries of struggle, are at last coming to terms with tuberculosis.

\section{OTHER SOURGES OF INFORMATION}

Fortunately, there are sources of information ancillary to the statistical, which may be sought in contemporary literature, biography and art: some of these have been mentioned already as the sole record of the position many centuries ago; others, of more modern times, must be reviewed in a little more detail, in particular literature-biography, autobiography and fiction-from the beginning of the eighteenth century.

Shakespeare (died 1616 ) was exceptionally well-informed on medical matters and it is difficult to find any great author, not a doctor, who so often refers to the healing art (Bucknill). His infrequent allusion to 'consumption' and the rare references to its classical symptoms are, therefore, pointers to the impact of this 306 


\section{The Impact of Tuberculosis on History, Literature and Art}

disease on the life of his times. This lends support to the view that it was not until after his death that the sharp rise in incidence began. It is true that 'wasting disease', 'phtisick' (phthisis), 'rotten lungs', 'wheezing lungs' and 'lethargies' are spoken of in many of his plays, but the words seem to be applied indefinitely, relating to syphilis, ague and other conditions as well as to tuberculous disease:

... a rascally phtisick so troubles me ... I have a rheum in my eye too, and such an ache in my bones.- Troilus and Cressida.

Consumption sow in hollow bones of man.-T imon of Athens.

I was told you were in consumption.-Much Ado About Nothing.

Side stitches that shall pen thy breath up.-The Tempest.

Pale primroses that die unmarried ... most incident to maidens.-The Winter's Tale.

After I 700, novelists allude to symptoms and effects more often and descriptions of the pale heroine languishing in a decline are not hard to find, but usually the writers avoided the dreaded word 'consumption'. Consumptive children, said a writer in a popular work of the nineties, are the novelists' favourite little heroes and heroines, who appear like fairies to gladden the hearts of parents and friends for a short season. Victorian song writers also liked them. It is only in the past few decades, as the stigma has slowly disappeared, that tuberculosis has been named with any frequence; nowadays no details are spared of the early symptoms, the rigours of sanatorium treatment, and the dramatic episode of the sudden haemoptysis. (E.g. The Plague and I, Betty Macdonald; The Print Petticoat, Lucilla Andrews; Three Comrades, Erich Remarque.)

Swift, in The Tale of a Tub (1689), does describe languishing consumption, 'whose tainted breath destroys unhappy infants'; so does Fielding in Tom Fones ( 1740 ). Samuel Richardson, the author of the first English novel ( 1740 ) makes Clarissa, in the book of that name, die of a decline, aged nineteen. Elaine in The Morte d'Arthur of Malory (1470) may well have been the first young lady of the English romance to have been so afflicted. The decline associated with the emotional disturbances of an unhappy love affair was a popular theme with Victorian novelists like the Brontës and Jane Austen, who were themselves tuberculous. You will remember Helen Burns in Fane Eyre (1847) who died of semi-starvation and neglected colds; and 'the vanished bloom and wasted flesh' in Shirley (1849), also written by Charlotte Brontë, about her sister. There were many more who 'faded like any flower in drought'. The closing scenes were usually happy, quite unlike those occurring in real life (there are no major crises in Jane Austen's works and no deaths). In considering these characters, it is to be noted that many authorities today believe that emotional and mental upsets act as exciting causes of active tuberculosis, and Kissen and others speak of a break in the 'love-link' in this connexion. One other youthful victim should be mentioned, poor Smike in Nicholas Nickleby, 'with sunken eyes too bright and hollow cheeks too flushed'.

Smollet, who had no success as a doctor, wrote admirably, despite his illtemper and vindictive nature: he had tuberculosis himself and wrote of it in many of his books. This passage is from Roderick Random (1 748), about a sick parade at sea: '. . . one (sailor) complained of a pleuritic stitch and spitting of 


\section{H. D. Chalke}

blood for which the doctor prescribed exercises at the pump to promote expectoration. In less than half an hour he was suffocated with a deluge of blood.' (When tuberculosis was rife, the early symptoms of lassitude and a dislike of work were often mistaken for indolence.) Tuberculosis was long an occupational disease of seamen: an epidemic occurred in the fleet blockading Brest in I809. Washington Irving writes about the pressed sailor who dragged his wasted body homeward to repose and die (England's Rural Life and Christmas Customs). Unsatisfactory, overcrowded quarters, were conducive to contact infection, and when 'a long sea voyage' was a popular therapeutic measure for the consumptive, sources of infection were not lacking. Charles Kingsley (he had chest disease all his life, dying in 1875 ) shows how readily infection was spread in those days, when people like the ploughman's consumptive daughter slept in a stifling lean-to together with members of her own family, her baby and a newly married couple ( east). Kingsley's publisher and friend was Daniel Macmillan (40) who had to contend with the millstone of tuberculosis all his life.

One more novel is selected, this time from France-La Dame aux Camelias by Dumas fils (1848). It is based on the real-life story of Marie Duplessis, a kept woman, who had what she described as 'one of those diseases that never relent. I shall not live as long as others, I have promised myself to live more quickly'; she died at twenty-three.

Katherine Mansfield, in her letters, gives a realistic picture of her conflict with an ailment which ended with a haemorrhage.

\section{Tuberculosis Among Writers}

Numerous literary celebrities were themselves tuberculous; others may be presumed to have been affected, but biography often hides the truth and before the days of bacteriology and radiology, diagnosis must have been in doubt very often. Here are some names:

The Brontës (29) (30) (39); Jane Austen (4I); Katherine Mansfield (35); R. L. Stevenson (44); D. H. Lawrence (45); Ll. Powys (55); Sterne (55); Smollet (50); Mrs. Henry Wood (73) - she had spinal disease and wrote from a wheelchair. (In Channings Jenkins had a 'Ghurchyard cough . . . a sort of decline, my wife and brother died of the same thing sir'.) Kingsley $\left(5^{6}\right)$; Orwell (46).

And from abroad:

Edgar Allan Poe (40); Thoreau (45); Whittier (85); Washington Irving (76); Chekov (44); Schiller (46); Balzac (52); Molière (5I); Prosper Mérimée (67).

Poets

Poets are prominent in the list and more of them died young than other writers. Poets, unlike most other geniuses, do not need a long life to achieve immortality, a few lines may suffice. Those who had consumption seem to have written with a hectic urgency, as though knowing that their time was short; a certain melancholy, symptomatic of their illness, is not unusual. Descriptions of 308 


\section{The Impact of Tuberculosis on History, Literature and Art}

the decline, always clothed in poetic euphemism, are to be found in great number: e.g. 'Where youth grows pale and spectre-thin and dies' (Keats); 'And melancholy marked him for her own ... he gave to misery all he had, a tear' (Gray).

The list of English poets is headed by Lovelace (40) who 'grew very melancholy, which brought him at length into a consumption'. His circumstances became so reduced that when he died in 1658 he was in rags and lived with beggars. Others, with dates of death, are:

Oldham (38) 1688; Philips (32) I 708; Hughes (42) I 719; Gay (47) I 732; ? Littleton (64) I 773; Keats (24) I82 I; Shelley (30) drowned I822; Hood (45) 1845; Gray (23) r86r; E. B. Browning (55) r86r; Symonds (53) 1893; Thompson (48) 1907; Flecker (31) 1915; W. E. Henley (54) 1903, who was lame following the amputation of a tuberculous foot, was the prototype of Long John Silver, in his great friend R. L. Stevenson's Treasure Island.

Dylan Thomas (39), the modern poetic genius, did not suffer from tuberculosis, but, according to a biographer, he imagined he did; a belief which may have served as an excuse for his alcoholism. Death is near in all his verses and he had an obsession that a poet should die young and 'live in such a way as to risk his own destruction'.

These few names are of poets who, despite short lives, lasted long enough to become famous thanks sometimes to their ability to move to a more equable climate abroad; in others biographical details are obscure, but suggestive; many more must have died young and unknown.

Close contact in the home has always been the most potent means of passing on the infection, and many of the famous people under discussion were members of tuberculous households, among them the Brontës, Keats, Baillie, Hood, Smollet, Chekhov, Trudeau. De Quincey, Rembrandt, John Hunter and others in this category seem to have escaped active disease. The home-life of the members of these families was disturbed by poverty, the loss of a parent, the despairing atmosphere of long drawn-out sickness and the fear that they themselves might be similarly stricken. Tuberculosis, then, must be included among the causes of an unsatisfactory upbringing, leading to a feeling of insecurity, which is at the root of behaviour problems making their appearances later on. Poverty was the usual accompaniment of early years in the literary and artistic fields and this and an unsettled way of life favoured a lowering of resistance at a time when none could avoid infection. Sometimes drugs and alcohol were superimposed on the toxins of the tubercle bacillus.

Edgar Allan Poe may be cited: he lost his father when he was a year old, his mother after a lingering illness when he was three and a half, his frail, exquisitely beautiful wife Virginia, also tuberculous, died shortly after a marriage lived in penury and squalor. She appears frequently in his poems:

... respite and nepenthe from the memories of Lenore.

... the wind came out of a cloud by night, chilling and killing my Annabel Lee. 


\section{H. D. Chalke}

\section{Musicians}

Purcell (37), who died in 1695, is the earliest English composer on the list; he caught a chill, said a biographer, after being kept outside his house by his wife as a punishment for keeping late hours! Many circumstances have been blamed for the onset of phthisis, but none as naive as this. Chopin (40) is the classical type and his temperament is clearly reflected in his music. Nevin (39), a lyrical genius who wrote The Rosary, struggled without avail against his ill-health. There are more names, including those of instrumentalists and singers. Mimi in La Boheme and Violetta in La Traviata are operatic consumptives.

\section{Painters and Paintings}

Relatively few artists appear to have been afflicted (although many must have died young before time was allowed them to achieve fame, their deaths accelerated by the conditions under which they lived); there are at least three notable exceptions:

Watteau (37), perhaps the greatest eighteenth-century painter, had an unhappy life. He was ill-fed and worked with feverish haste for long hours, painting exquisite romantic scenes which were in sharp contrast to the gloomy melancholy of his own life. He died in $172 \mathrm{I}$.

Modigliani $(36)$, an original genius, who died 200 years after Watteau, lived imprudently and defiantly, sustaining himself with alcohol and drugs and subsisting on a diet which, it is said, consisted mainly of sardines. His portrayal of young ladies with slender necks, slanting shoulders and peach blossom complexions-Mlle Victoria, the English girl, was the model for many of them-is characteristic.

Aubrey Beardsley (27), was an unconventional black-and-white artist, the originator of a new cult. Seldom has anyone produced so much in such a short time, his friends attributing his abnormal activity to a desire to forestall death and leave a legacy.

\section{Portraits}

Portraiture supplements biography. There can be few galleries lacking a canvas or two showing a possibly tuberculous subject. The tuberculous type has long been recognized. Hippocrates wrote of those most liable, as having smooth, fair, ruddy skins, blue eyes and shoulders projecting like wings. The nineteenthcentury writers gave pictures of the same kind. One of the most colourful is in Lavengro ( $185 \mathrm{I}$ ), believed to be George Borrow's own biography; he describes his brother in these terms:

... a rosy angelic face, blue eyes and light chestnut hair . . . it partook to a certain extent of the Geltic character, particularly in the fire and vitality which illumined it. So great was his beauty in infancy that people would follow ... and bless the lovely face. Perhaps it will be asked here what became of him. Alas! his was an early and a foreign grave.

He became a painter, and was 'pale and unwell' on his last visit to his home. 3 IO 


\section{The Impact of Tuberculosis on History, Literature and Art}

Unfortunately the reader is not told how and where he died. Another writer (189I) noted that:

Children prone to tuberculosis are generally pretty, slim, fair-haired with lithe active figures, delicately formed limbs, slender chests and waists, blue eyes and clear red and white complexions. They are intelligent, quick, volatile and a source of pride to their mothers and nurses. The tubercular children are pretty, the scrofulous children ugly.

Children of both types are to be seen on many a canvas, but, regretfully, the fate of the sitters is seldom known.

Experience in a twentieth-century tuberculosis dispensary hardly supports such a dogmatic opinion, ${ }^{*}$ which confused predisposition with the visible effects of active tuberculosis, and was based on the premise that the disease was hereditary. These oft-repeated statements are, notwithstanding, of great interest, and there are many geniuses such as Shelley, to whom the description applies.

Fortunately the portraits of many persons-especially young ladies-known to have been tuberculous, are available for study. Models often chosen by the Great Masters for their beauty, languor and appealing sadness of expression, were often in the sickness of tuberculosis.

Botticelli, in his Venus and other paintings, idealized Simonetta the Florentine beauty, who died tragically in 1475 at the age of sixteen. Her counterpart was popular with many of his successors. The ethereal type became so fashionable that young ladies sought to emulate it by eating sand or drinking vinegar and lemon-juice to destroy their appetites (Dubos). This must have been a disastrous procedure in the days when tuberculosis was epidemic. Fashions do not seem to have changed much, but fortunately the teenagers of today with too much eye-shadow and mascara, which make them look fatigued and debilitated, run less risk of tuberculosis infection: we see them on television, sometimes, in plays and advertisements.

The pre-Raphaelite painters of the mid-nineteenth century (the founders of the aesthetic movement, which included Dante Gabriel Rossetti, Burne Jones, Holman Hunt, Millais, as well as John Ruskin and the poets Swinburne and William Morris) depicted pale, distraught young women, with sad and tired faces; the painters, like the poets, favoured morbid melancholy, which-without knowing, perhaps, the pathological reasons-they found in the young adult consumptive. One such was the beautiful Elizabeth Siddal, a tragic and temperamental beauty (Ruskin gave her $£$ I50 a year to enable her to go abroad for her health), painted many times by Rossetti (The Annunciation, Beata Beatrix). He married his model, but after two unhappy years she died of an overdose of laudanum. She appears in pictures by Millais-Ophelia is her best likeness $\uparrow-B u r n e$ Jones and Holman Hunt. William Morris's wife, Jane Burden, another supposed consumptive, sat for his friend Burne Jones (Circe and ? Cophetua), and also to Rossetti (Queen Guinevere).

\footnotetext{
* Careful recording over many years, of physical characters of patients with early tuberculosis did not suggest a preponderant type, but racial types (e.g. Irish and Welsh girls) with low resistance were noticeable in many clinics in urban England.

t The pre-Raphaelites always 'painted from the real thing', and it is said that the cold bath in which she sat as a model for this picture 'nearly killed her'.
} 


\section{H. D. Chalke}

Rembrandt, a keen student of the human face and its changes of expression, was deeply affected by the loss from phthisis of his wife Saskia (33) and son Titus (28). His portraits of them leave little doubt about the correctness of the diagnoses.

The Linleys of Bath, a gifted musical family, knew to the full the tragedy of tuberculosis, which left hardly any survivors among twelve children. There are many paintings of them by Reynolds, Gainsborough and Lawrence, which like all masterpieces must be seen in the original to be appreciated. The two elder sisters, Elizabeth (Mrs. Richard Brinsley Sheridan) (39), and Mary (Mrs. Tickell) (29), were opera singers, and among the beauties of the time, who are shown together in a wonderful picture by Gainsborough, which immortalizes the delicate beauty and fragility of their disease. Elizabeth was the model for Reynolds' St. Cecilia and The Nativity. The progress of the decline, the ultimate result of which they foresaw only too well, was similar, step by step, in both sisters; children of both of them also succumbed in infancy.

\section{Doctors}

Phthisis has not spared doctors. Laennec (45), famous for introducing the stethoscope, was himself diagnosed by his own method of mediate auscultation. Kipling tells a delightful tale about him (Marklake Witches) in which, as a prisoner-of-war in England, he learned the use of the tube of holly wood from a witch wizard and diagnosed a young girl with 'cheeks pale except for two pretty pink patches ... little gasps at the end of her sentences as though she had been running'. Baillie (62), who wrote the first English textbook on pathology, describing the grey tubercle, was delicate, but worked at a feverish pace. He died of consumption. His mother was a sister of the great John Hunter; she and five of her brothers and sisters died of phthisis: 'the genius of the Hunter family, like that of the Brontës, was much frustrated by this disease'.

Thomas Beddoes, a notable physician who died in 1808 , gave much to the literature of tuberculosis. He advocated treatment by inhalation (which afterwards he abandoned), and it is interesting to note that the superintendent of the pneumatic institute, as it was called, was Humphry Davy, who whilst there discovered the anaesthetic properties of nitrous oxide.

\section{Genius}

The researches of Havelock Ellis revealed that tuberculosis was the cause of most of the deaths of the more eminent men who died young; some poets and a few others excepted, great men live long, because they must do so to achieve eminence. The high proportion of philosophers, thinkers and reformers among tuberculous geniuses is noticeable. In their survival to middle age and beyond, they fought a hard battle against their affliction:

Spinoza (45); Descartes (54); Rousseau (66); Butler (68); Locke (72); Kant (80); Voltaire (84); Emerson (79); Ruskin (81).

Doctors and scientists include:

Priestley (71); Black (71); Matthew Baillie (62); Hans Sloane (92); Dettwaller (67); Trudeau (67). 


\section{The Impact of Tuberculosis on History, Literature and Art}

Descartes, the father of modern philosophy, after living a secluded life for twenty years, went to Sweden at the invitation of Queen Christina. His weak constitution, writes a biographer, was overcome by the hard Scandinavian winter, and 'the exposure involved in waiting upon the Queen at five every morning for an hour's philosophic instruction'!

Spinoza. His sickly constitution forced him to devote the whole of his life to study. He learned the craft of lens polishing, and because he would accept no financial help, this became his only means of sustenance. His illness progressed steadily, aggravated, no doubt, 'by the glass dust from the lenses, which had done its worst'.

Sir Hans Sloane was always delicate; he had haemoptyses between 16 and 19 years of age, but he lived a careful and prudent life, reaching the great age of 92. He left 8o,0oo specimens, zoological and botanical, which formed the nucleus of the new British Museum. He followed Newton as President of the Royal Society.

Edward Livingstone Trudeau, the founder of the world-famous sanatorium in the Adirondacks, developed extensive tuberculosis at 25, infected, it is said by his brother whom he nursed during his fatal illness, a little time before. His own daughter was also a victim-Trudeau never recovered from the shock.

Fohn Ruskin. At 2 I, at Oxford, 'he was seized with a consumptive cough and spat some blood', but unlike so many of the young geniuses of the time, this was not in his case the death warrant, for after two years' sojourn in Switzerland, Italy and other places, he seems to have recovered completely, out-growing 'his tendency to consumption'.

Cecil Rhodes (49) was another whose 'health broke down' in adolescence, and again at Oxford. Destined for the Church, his poor health was the reason for his abandonment of this career and instead joining his brother in Natal. At $2 \mathrm{I}$ his chest condition was such that a London physician gave him six months to live. He was impressed by 'a sense of the shortness of life' which must have had a profound effect on his character and activities.

Foseph Priestley, the discoverer of oxygen, had to give up school for a time because of ill-health. Whether or not he had tuberculosis cannot be affirmed with certainty; it is worth noting, however, that he lodged at one time with the Linleys of Bath, and was closely connected with the family affairs. His sister was treated by Dr. Beddoes when in the advanced stages of consumption: the protean treatment of those days is well illustrated by the tale that she found almost every symptom alleviated (temporarily, no doubt) on the second night after a stay in the cow-house!

It has been said that the toxins of tuberculosis stimulate the creative instinct and promote literary brilliance (Moorman, Marks); some go further, asserting that the quality of writing declines with quiescence of the disease. R. L. Stevenson believed that this happened to him, but he could hardly speak from personal experience, for the miraculous quiescence which he said brought him back from semi-death to life, if it did occur, was short-lived: and in his last years in Samoa his literary powers showed no signs of waning-neither, perhaps, did 


\section{H. D. Chalke}

the activity of his pulmonary lesion-although the cause of his sudden death is uncertain. The characteristic urge to produce, and produce at speed, whether due to toxaemia and pyrexia, or the fear that the tide is fast ebbing, was shown by Stevenson, when, extremely ill and bedridden at Bournemouth, he wrote Dr. Fekyll and Mr. Hyde in three days. It will be recognized also that for Stevenson and very many like him, no domestic stability was possible during a lifetime of movement from one place to another in the illusory search for surcease of illhealth.

A delicate constitution in early life, not rare in those who later became famous, restricts physical activities, giving a preference for the study to the playing field, with ample time for contemplation and scholarship. A feeling of physical inferiority may guide the thoughts down the pathways of reform or embittered revolt; a vein of gloom and melancholy running through the writings of certain of the poets is symptomatic, yet a few, like Hood, were able to laugh often and say: 'Here lies one who spat more blood and made more puns than any man living', as he lay in bed propped up with pillows, 'and grave and dejected of mien'.

It is intriguing to give play to the imagination and to consider what geniuses like Keats, Chopin and Watteau might have given to the world had they lived on, and to think of what mankind would have lost had tuberculosis cut short the lives of such as Shakespeare, Milton, Newton, Rembrandt, Beethoven, Rutherford or Fleming.

\section{OTHERS}

The grim catalogue has many more entries, not only of personalities in the realms of literature, science and the Arts, but of men and women-honoured and dishonoured-in other walks of life. Then there is that incalculable number of unknowns that makes up communities and nations, whose personal and collective ill-health has conditioned national life and economy. This, the most important group of all, would need much more time to discuss than is available. Again, there are people of widely divergent backgrounds, such as Grace Darling (27), the heroine of the Farne Islands; Charles Byrne (22), the ginsodden $7 \mathrm{ft} .7$ in. giant (his skeleton hangs in the Royal College of Surgeons) whose last days were spent in fear-which despite his lead coffin, proved to be justified-that his body would be snatched for John Hunter's dissecting table; and, quite recently, Gilbert Harding, who submitted to treatment with reluctance; the self-denying Simone Weil (43) in 1943.

\section{Individuals Who Have Made History}

The pages of history are not lacking in names of men and women, famous or infamous, in whom sickness of the mind or body has governed behaviour. Tuberculosis has played a part, and this paper would be incomplete without a selection of those who by their conduct or early death have changed history.

Hadrian, who died in A.D. 138 (62), was supposed to be tuberculous, but his last illness, during which his character changed and his good was forgotten, 


\section{The Impact of Tuberculosis on History, Literature and Art}

was more probably heart failure. Lucius, the young eccentric dilettante he named to succeed him, was soon wasting from consumption and died of a haemorrhage shortly afterwards. (Marcus-the great Marcus Aurelius-took his place.) Virgil's lines were quoted by Hadrian: 'This hero Fate will not display to Earth, Nor suffer him to stay' (Perowne).

Edward VI, who died in I 553 (I5), had a visible and swift decline and a violent cough which nothing would relieve. His death was attributed to 'quack nostrums on a consumptive frame'. Northumberland acquired great influence over the ailing boy, to name Lady Jane Grey to succeed him. Had Edward not died, England would have been saved the bloodshed of Mary's reign.

Madame de Pompadour (43), the butcher's daughter, died after a rapid loss of weight and extreme emaciation. Her influence over Louis XV was disastrous for France in wars, loss of colonies and depletion of the exchequer. She overthrew the political systems of Europe. 'What remains of this woman', said Diderot, 'who cost so much in men and money?' She helped to bring about the French Revolution. Rousseau, another (?) consumptive, paved the way.

Napoleon's son (2 I), brought up in Austria, was frustrated and bewildered. Always delicate, he was pale with a constant cough, and later, fever, rigors and blood-spitting. Until almost the end he was diagnosed as suffering from a liver complaint, and persisted in arduous military activities until just before death. Had he lived and become Emperor-as a large section of the French population hoped-France might have been saved years of turmoil. (The necropsy on Napoleon at St. Helena showed 'tubercles on the lungs but ... a vast cancerous ulcer at the pylorus.')

Gavrillo Princip (22), the young Bosnian Serb whose assassination of the Archduke Franz Ferdinand at Sarajevo in July, I914, was the immediate cause of the First World War, was a small, thin, delicate youth with early phthisis, unfit for military service. A ready tool in the hands of the revolutionary Black Hand Society, his spes phthisica was a martyr's crown. His companion in crime, Chabrinovitch, attempted, unsuccessfully, to kill the Archduke with a bomb before Princip fired. He also was in poor health; discontented, bad-tempered and unhappy at home, he knew he had not long to live and was impatient to carry out the deed and take the cyanide which the plotters gave him. He was captured and died of tuberculosis in prison in 1916, two years before Princip. In infamous immortality they achieved the recognition for which they craved.

Before and since, there have been many young criminals with a similar background and outlook; fortunately, their deeds have seldom had such appalling consequences.

\section{GONCLUSION}

This brief review has presented only a broad picture of the tuberculosis scene over the centuries. Inevitably much of it is hazy, for a disease so ancient has left scant record of its origins, early incidence or distribution; it follows, therefore, that, like the world history of which they are a part, the happenings of long ago are full of speculation, and what little evidence there is has been acquired 


\section{H. D. Chalke}

indirectly. Despite the paucity of fact, there is a likelihood that the infection (which may have been of bovine origin) spread from the east, carried by manand his animals - in the drift to the colder and damper climates to the west and north-west, where, some historians say, he was prone to affections of the lungs.

The written records of successive civilizations yield more information, both positive and negative, and there is a mass of knowledge about Greco-Roman times, but, unfortunately, the Hippocratic school had no statistical method. Far less is known of the thousand years that followed-the Dark Ages when medicine made little progress. During the Renaissance, when modern history commenced, events began to be chronicled more frequently and more faithfully in lay and medical writing. But we have had to wait much longer for an acceptable statistical record and even now this is by no means complete.

The historical record would have been even more meagre had it been restricted to medical treatises; fortunately, it can be supplemented by biography and contemporary literature: portraits, too, may help fill in the gaps, and even cave pictures and figures on pottery have something to offer. Evidence of spinal caries in Neolithic skeletons and Egyptian mummies has confirmed the antiquity of the disease: with the advances being made in palaeopathology much more information may become available soon about the location and date of early tuberculosis in man and animals.

The biographical field is itself limited. Next to nothing is known of the lives of many poets and others who were cut off early; even when the biographer has more to relate, there may be the vaguest of references to health or a predilection to avoid the use of gross words like 'consumption'. The perplexed medical historian sees the force of Stendhal's dictum that a part of every man's biography should be written by his doctor. The sketches made here are limited to certain celebrities whose personal stories are well authenticated; some illustrative passages from authors whose observations are believed to be reliable have also been given.

But the immortals form a minute part of the multitude of consumptives-the undistinguished, the ordinary men in the street-whose biographies have never been written (except in medical books, and in sanatorium and tuberculosis dispensary files of this century). Other than as prototypes of fictional characters, sometimes, they are only recognized in the mass, on account of their collective influence on national health and welfare. Tuberculosis, a chronic complaint, has been with the world for a long time, and its insidious repercussions though less dramatic than those of, say, plague, typhus or the sweating sickness, have been no less serious. Ill-health restricts working time, lowers productivity, calls for expensive medical care and influences national prosperity. Economic depression is a reason for emigration, which takes the fit and leaves the afflicted behind, and, conversely, immigration has more than once brought fresh sources of infection to this country. More than anything else, a poor national health standard, with its attendant misery, has always been the foe of happiness and contentment which are the pillars of a successful and peaceful community existence. 


\section{The Impact of Tuberculosis on History, Literature and Art}

Whatever may have happened in the remote past, it is certain that the behaviour of phthisis in this country, and in western Europe generally, during the last three hundred years is without precedent. The sudden upsurge, the long phase of sustained activity, the slow decline and now the more rapid abatement as treatment has become effective, give a true picture of tuberculosis as an infectious disease, which differs from that of epidemics of acute infections only in time. Saturation of infection has ended, as herd immunity has increased, to be replaced by small foci, which are capable of being obliterated if detected early. The main reservoir is found in older males-a phenomenon which may be a reflection of living conditions at the turn of the century. At long last, thanks to vigorous action, intensified during the past decade, the centuryold menace of infected cattle has almost disappeared.

The epidemiologist of today is fortunate in having morbidity and mortality tables, tuberculin conversion rates and radiographic surveys to help him, but essential though they are, they tell only part of the story. Figures are impersonal, revealing nothing of the deep effects these changes have had on people, homes and communities. It is here, again, that the biographer, novelist and historian come to our aid and allow comparisons to be made between the distressing situations of yesterday and the happier state of affairs today, as a great burden is being lifted gradually from society and the words 'consumption', 'phthisis' and 'decline' are becoming ever less descriptive.

This is not the place to discuss why all this has come about, nor to try to enumerate and assess the relative importance of the many interacting contributory factors, which, if they have not yet vanquished the tubercle bacillus, are, at least, enabling man to come to terms with it.

The grim story of the past should not be forgotten; it should serve as a spur to a united effort to try to give the coup de grâce to this invader from which the world has suffered so severely and for so long.

\section{BIBLIOGRAPHY}

Aldington, R. Portrait of a Rebel. London, 1957.

BATEMAN, T. Report on the diseases of London. London, I819.

BELL, W. G. Great Plague in London in 1665 . London, 1924.

BeLOes, T. Causes, early signs and prevention of pulmonary consumption. Bristol, I 799.

BERDOE, E. Origin and growth of the healing art. London, 1893.

BRAY, W. Fohn Evelyn's Diary. London, 1870.

BrowNLEe, J. Investigation into epidemiology of Phthisis. London, 1918.

BuGKNILL, J. C. Shakespeare's Medical Knowledge. London, 1860.

BURKE, R. M. Historical chronology of tuberculosis. Baltimore, 1938.

Gastelot, Andre. Napoleon's Son. London, I96o.

Goulton, G. C. The Black Death. London, I929.

GRAwrurd, R. The King's Evil. Oxford, I9I I.

Dictionary of American Biography.

Dictionary of National Biography.

Dubos, Rene. Mirage of Health. London, 1960. 


\section{H. D. Chalke}

Ellis, Haverock. Study of British Genius. London, I904.

Encyclopaedia Britannica.

F ay, S. B. Origins of the World War. Vol. n. New York, 1929.

Francis, J. Symposium of tuberculosis (Ed. F. R. G. Heaf). London, I957.

Frase R, J. Short History of some common diseases (Ed. W. R. Brett). Oxford, I934.

Frazer, Sir James. Golden Bough (Abr. edition). London, 1922.

Frazer, W. M. A. History of English Public Health. London, 1950.

FREIND, J. History of Physick. London, 1727.

Giles, J. A. Old English Chronicles. London, 1885.

Bede, Ecclesiastical History. London, 1900.

GRAUNT, J. Natural and political observations on bills of mortality. London, 1662.

Greenwood, M. Epidemics and Crowd Diseases. London, 1935.

HU BE R, J. B. Consumption, its relation to man and his 'civilisation'. Philadelphia, r 906.

Hughes, T. Memoirs of Daniel Macmillan. London, 1883.

KEMBLE, J. Idols and Invalids. London, 1933.

KISSEN, D. M. Emotional factors in pulmonary tuberculosis. London, 1958.

KOBLER, J. Reluctant Surgeon. London, 1960.

Lewis, D. B. Wyndham. Molière, the Comic Mask. London, 1960.

Louis, P. C. A. Researches in Phthisis (Tr. W. H. Walsh). London, 1844.

Marks, Jeannette. Genius and Disaster. London, 1928.

Meinecke, B. Ann. Med. Hist. I927, 7, 379.

MERYON, E. History of Medicine. London, I86r.

Moorman, L. J. Tuberculosis and Genius. Chicago, 1940.

Morton, R. Phthisiologica. London, 1689.

Moyes, J. Medicine in Shakespeare. Glasgow, r896.

Neuburger, M. History of Medicine (Tr. E. Playfair). London, 1910, 1925.

NewSHOL ME, A. Elements of Vital Statistics. London, 1923.

Nicolson, H. Age of Reason. London, r96o.

REID, J. G. Francis Thompson. London, I 960.

Rogers, Sir Leonard, and Muir, E. Leprosy. Bristol, 1940.

Roney, J. G. 'Palaeopathology of a California Archaeological Site', Bull. Hist. Med., I 959, 23, 97.

Rowling, J. Thompson. Proc. roy. Soc. Med., r96r, 54, 409.

Salmon, Andre. Modigliani: A Memoir. London, I96r.

Simpson, R. R. Shakespeare's Medicine. Edinburgh, I959.

SOU THEY, H. H. Observations on pulmonary consumption. London, I814.

Tedlock, E. W. Dylan Thomas. London, ig6o.

Whe atrey, H. B. Diary of Samuel Pepys. London, 1928.

WOо Lсом ве, W. Frequency and fatality of different diseases. London, 1808.

Young, T. A. Practical and historical treatise on consumptive disease. London, 1815.

\section{ACKNOWLEDGMENT}

I am much indebted to Miss G. Johnson, F.L.A., Chief Librarian and Curator, and the staff of the Camberwell Central Library, for their generous assistance in the bibliography. 